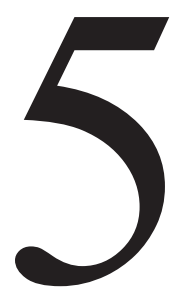

\title{
The Foundations of American Imperial Education
}

\author{
Los fundamentos de la Educación \\ Imperial Estadounidense
}

\section{Ronald K. Goodenow*}

DOI: 10.5944/reec.31.2018.21591

\author{
Recibido: 12 de marzo de 2018 \\ Aceptado: 30 de marzo de 2018
}

\footnotetext{
*Ronald Goodenow, Ph.D. (Berkeley), now an independent scholar, has held academic and research appointments at several American and British universities, including the State University of New York at Buffalo, the University of New Hampshire, Columbia University, the City University of New York, the University of London Institute of Education, the University of Liverpool and the Crummer Graduate School of Business. He has given Fulbright lectures in the UK and Brazil, published four books, and published extensively in his chosen fields of history, comparative studies and information technology services in education and healthcare. Current areas of interest include the value and uses of communications technologies internationally, and looking critically at the role of business schools internationally. Recent publications include "Paradigms and Practice: Perspectives on Ever Shifting "Telework Sands", a chapter in Elizabeth Christopher (ed), Managing Communication Across Cultures: Different Voices, London: Palgrave MacMillan, 2012, and "Sevice Across Cultures: A Case Study of the Emerging Role of Communication Technology in Rotary International," a chapter in Elizabeth Christopher (ed), International Management and Intercultural Communication; a Collection of Case Studies, London Palgrave MacMillan, 2015. Datos de contacto: E-mail: ron.goodenow@gmail.com
} 


\begin{abstract}
The evolution of American educational imperialism is presented, beginning with colonialism in territories obtained from Spain in the early 2oth century through the US occupation of Germany and Japan after the Second World War and then through the Cold War and post Cold War periods. A selection of examples will discuss basic foundations of American educational imperialism, including values and ideals, international exchanges, philanthropy, education in select Muslim countries, business education, and collaboration between 'hard' and 'soft' power aspects of imperialism. It is noted where this collaboration has either failed or led to catastrophic outcomes. Major shifts are noted to correspond to changes in US public, political and popular attitudes. Conclusions regarding the shape of and shifts in educational imperialism are provided. It will be seen that much of what is observed is a 'mix' of politics and practicalities which produced a mix of outcomes.
\end{abstract}

Key Words: soft power; colonial; occupation; philanthropy; exchanges; educational progressive

\title{
Resumen
}

Se presenta la evolución de la educación en el imperio estadounidense, comenzando con las colonias en los territorios obtenidos de España a principios del siglo XX, pasando por la ocupación estadounidense de Alemania y Japón después de la Segunda Guerra Mundial y luego durante la Guerra Fría y los períodos posteriores a la Guerra Fría. Mediante una selección de ejemplos se discutirán los fundamentos básicos del imperialismo educativo estadounidense, incluyendo los valores e ideales, los intercambios internacionales, la filantropía, la educación en determinados países musulmanes, la educación empresarial y la colaboración entre los aspectos del hard power y el soft power del imperialismo. Se señala dónde esta colaboración ha fallado o ha llevado a resultados catastróficos. Se observa que los cambios principales corresponden a cambios en las actitudes públicas, políticas y populares de los Estados Unidos. Se brindan conclusiones sobre la forma y los cambios en el imperialismo educativo. Se verá que gran parte de lo que se observa es una «mezcla» de política y aspectos prácticos que producen una combinación de resultados.

Palabras clave: soft power; colonial; ocupación; filantropía; intercambios; progreso educativo 


\section{Introduction}

American education in possessions and areas of influence from the late $19^{\text {th }}$ century until the late $20^{\text {th }}$ century has expanded from its place in somewhat limited colonial control, to post-war occupation to participation in an extremely diverse, constantly changing and vast set imperial initiatives known to create 'The American Century' or, given the overwhelming power of the US, a 'Pax Americana'.

This road to imperialism went through growth stages and follows decades of European colonial practice in various North American geographies, and United States ones in the conquest of Native American territories in the $19^{\text {th }}$ century.

This essay, however, chooses to dwell on a period after the United States assumed status as the world's largest economy and in the early years of the $20^{\text {th }}$ century focused on its consolidation of colonial power in Asia and the Caribbean as a precursor to expanded economic power.

In the sections on acquisitions from the Spanish may be seen the building of bureaucratic, knowledge transfer, relationship building and training mechanisms to give schooling a firm and formal location in the growth of what would become the full-blown cultural/educational imperialism discussed in the article. This said, it should be recognized that the emphasis among those responsible for this phenomenon were primarily concerned with setting the parameters of the colonial relationship the paper considers, even if in the North American homeland there were those supportive of colonialism as a necessary first step to imperialism.

This was followed by a brief period of isolationism and America First motifs brought on by the First World War and strengthened by depression. Subsequently, the Second World War led to a period in which the occupation of Germany and Japan, and efforts regarding that, turned into Cold War strategies and investments. This led in the last fifty years to a vast set of military, economic and cultural engagements, some of which may be seen as 'soft power' and a foundation of educational imperialism, with others seen as a blending of the two.

A concept which emerged openly in the 1980 s by the work of Harvard political scientist Joseph Nye (2004), 'soft power' as a complement to 'cultural diplomacy' (a sometimes interchangeable term), referred, often very generally, to programs and initiatives which complemented, strengthened and masked imperialism by the US or other imperial nations. Whether sponsored by the government or NGOs, the idea is they supported American democratic and civic values without visibly promoting US foreign policies per se, making US involvement abroad more palatable internationally and at home where students, academics and members of the public acted in part out of idealism, or in some cases support for expansion of the American Dream to other populations at a time of US invasions and anti-terrorist warfare. Logically, given the opposition of many Americans to wars in Vietnam and the Middle East, many who formed or engaged in these programs did so out of opposition to imperialism, as did others who wished to defeat enemies of the US. For many students it was simply a chance to travel and see the world.

The shifting nature of this shaping of American imperialism means not only that new educational and other efforts emerged, but that there is considerable continuity. It must also be noted that foundations embedded in imperialism may contain laudable objectives and outcomes, including literacy, the education of girls, agricultural assistance, and disease eradication that represent highly visible tips on the imperialistic iceberg, which is a 
veritable mix of tools and processes which contributed to US cultural diplomacy by players both witting and doubtless unwitting. It is not the purpose of the essay to study the continuity of policies related to $19^{\text {th }}$ Century US educational practices for Native Americans, Afro-Americans and recent immigrant populations, save some mentioned with regard to the Philippines and Puerto Rico. This said, ideas assuming cultural and racial superiority, vocational and practical education, elite formation, 'community education' and other characteristics morph, change and are applied throughout the $20^{\text {th }}$ century.

The subject is a challenging one, and two examples suggest its size. The US based Institute for International Education (2017) has 16,00o higher education partners, 700 staff world wide, 700 study abroad partners and 27,000 program participants. The United States Agency for International Development in the years 2011-2015 supported 151 basic education programs in 45 countries, benefiting approximately 42 million children and youth (USAID, 2017). In FY2016, combined US. Agency for International Development USAID and Department of State education programming alone amounted to about $\$ 856$ million (Tarnoff, 2016).

At its core the evolution discussed below was rich with ideas, which can be seen as marketing America's new responsibilities at home and abroad to be different from that of the 'greedy', e.g. traditional European imperial powers (to be kept out of Latin America by the Monroe Doctrine, enacted in the early $19^{\text {th }}$ century), or later, the remnants of empire and Soviet imperialism. As put by one commentator and will be illustrated in forthcoming discussion of many US programs, there was one common theme, closely related to 'soft power', at the core of much US educational imperialism:

"Ideology would play an important role in the US. imperial enterprise, far greater than it did with the European colonial powers where mission civilatrice, as in the case of France, was an afterthought, an obvious fig leaf for economic interests. Imperialism had to be legitimized to the American people" (Bello, 1998, p.367).

What follows is not program detail or insights into classroom practices, but examples which illustrate foundations in the shifts and shapes in the role of American education in select empire related times and places...a huge and complex topic. Their selection was made to provide a picture of the foundational components of an increasingly complex educational imperialism. No effort is made to compare them, or to suggest their ultimate weight, success or failure, except where they are highly visible. The essay also notes that educational imperialism and imperialism itself did not always run on parallel and successful tracks. In one case noted below it very possibly led to a devastating war that taxes America to this day. In another, a prominent philanthropy aided and abetted intelligence services which destroyed a democracy.

\section{Colonial Foundations - 1898-2017}

A brief perspective on the US role in the Philippines and Puerto Rico is therefore instructive because it illustrates the foundation of many educational ideas and practices on which subsequent policies emerged in non-colonial environments (Goodenow. 2018).

Key US strategies in the Philippines included, after a highly destructive rebellion at the beginning of colonial occupation, using the US military to staff and build new schools that reflected practices in the US, the military coming to play an important educational 
role in countries the US occupied after WWII as well. Subsequently, as a model going forward, the 1903 Pensionado Act, named after a ship which had taken students to the US, supported sending large numbers of Filipinos to the US for training as teachers and, eventually for some, administrators. Many of these 'Pensionados' stayed in the US or later returned to it, setting the stage for the large Filipino migrations of the $20^{\text {th }}$ century. Though not precisely an 'exchange' this program set in process a practice that was to be emulated over the next hundred years, albeit in many different forms, to introduce students and educators to America on a first hand basis.

Philippine schooling therefore incorporated ideas and features of American education that brought into play a visible mix and sometimes contradictory ideas and practices. Some of these were announced in public rhetoric to foster equality, secularism and modern practices...leading eventually to an independent democratic nation and support in the US. More likely to be used were philosophies derived from the education of AfroAmericans and Native Americans that were outside the domestic American mainstream, such as those incorporated the industrial 'working with one's hands' ideas of Booker T. Washington and his Tuskegee Institute, Native American boarding and day schools managed by missionaries.

This stew of pedagogy and Anglo-Saxon Protestant values which disdained "brown brothers", Catholics and "the natives" was applied commonly in the Philippines and Caribbean. Indeed, to this day American media and politicians commonly disdain foreign cultures, ethnicity and religions in ways that smack of racism and forms of American exceptionalism. This took place at a time when anti-immigration and racist theories were generated at America's leading universities, including Harvard and Stanford, racism was a powerful force in the post-Reconstruction South and Native Americans were losing land and increasingly confined to reservations (Solomon, 2013)(Navarro, 2010). Indeed, after defeating the Philippine rebels who led a major rebellion shortly after occupation it was bragged that Americans knew how to deal with disgruntled natives, having gained experience from the conquest of Native Americans (Justice, 2009), an unsubtle reference to hard power to justify soft power.

A major imperative in the early days was to work out complex issues surrounding religious and language instruction, utilizing resources that were both local and, for long periods in time, administered by the Catholic Church, particularly in remote areas. Efforts were made to equalize the schooling of boys and girls, though girls, encouraged becoming teachers, were more likely to be taught about needlework and other "practical" subjects than boys, with many other inequalities in terms of professional training and jobs (Sobritchea, 1996). The United States began a program to complement and replace an extensive system of twelve thousand public and private primary, secondary, and post secondary institutions of education (Angulo, 2012). Much single sex schooling was ended, and there was a major effort to establish post-secondary colleges and universities. A Department of Public Instruction was established in 1900. Similar efforts were made in Puerto Rico.

Apologists for the new American role argued commonly that educational establishments would put in place policies recommended or implemented by the American governor and appointed superintendents of public instruction, newly established legislatures with limited powers and various commissions and experts as schools were built and teachers trained. Administrative colonial systems and bureaucracies tended to parallel American ones which gave locals responsibilities and, to some degree legitimacy in the 
US - a hallmark feature of American administration in conquered territories through the $20^{\text {th }}$ century and beyond. In some instances, as in the case of Puerto Rico, beliefs about the impaired mental capacity of residents, in this case citizens after 1917 have restricted services and full citizenship opportunities into the 21st century (Stratton, 2016).

Indeed, to this day on the religious front, the Philippine and Puerto Rican systems include many Catholic administered schools and colleges of high quality, and are therefore more likely to serve and create elites than the public school systems (Clark, 2015). If new US projections of power opened the door to projects of economic and military advantage, they also contained seeds of democracy as schools were built, domestic teachers trained and hired, the bonds of religion loosened but not destroyed, and ideals and processes of future citizenship, particularly in the Philippines, promoted.

These practices would also be joined by others which called for more "modern" and "research based" policies, including "child centered" education, generated at leading American universities and public agencies throughout the $20^{\text {th }}$ century as psychologists and others studied "the whole child". A good and early example of this is the 1925 Monroe Commission Report on the Philippines which, sponsored by Teachers College, Columbia University, under the guidance of Paul Monroe, with the help of prominent US. educationist George Counts of Yale, himself a leading voice of progressive social reconstruction at home (Goodenow, 1975) (Cremin, 1964). The report urged modernized teacher training and more emphasis on historical, American usually, subjects taught in English (Counts, 1925).

This said, there could be considerable resistance. In Cuba, as an example, there was according to A.J. Angulo, very early opposition to the essentials of US. colonial schooling on the part of residents highly informed on educational issues. "They mostly wanted an elimination of English requirements in their schools, reintroduction of civics in the curriculum, an increase in teacher salaries, cutting the superintendent's centralized power" (Angulo, 2012, p.9). As time went on sympathetic American administrators eased up on English requirements. But they did maintain the idea that elites were to be trained to act like mainland citizens. This was brought about in part by subsidized training in the US.

In the case of Puerto Rico it was generally assumed that the Caribbean and much of Latin America was already an area of great US influence, an influence driven in part by the role of individual corporations and political leaders throughout the region for much of the $19^{\text {th }}$ century, reflected in the 1923 Monroe Doctrine restricting foreign involvement in Latin America. In both the Philippines and Puerto Rico the main American task was to systematize training and address educational and social ills though schooling. "Citizenship" was bestowed, but only in the case of the Philippines, was nationhood (after the Second World War) after a period as a commonwealth. In Puerto Rico it was highly restricted, with limitations on voting. Financial disaster, institutional contraction and the burdens posed by island mismanagement are now forcing what a recent study sees as a new emphasis on alternative approaches to education, of using distance learning teaching and technologies. It remains to be seen what the US influence will be. And whether Puerto Rico will ever achieve independence (Quintero, 2017). In Puerto Rico there is an extensive popular literature on the hypocrisy of modern colonialism, which on one hand promotes democracy and citizenship, and on the other denies it. This is also a time of massive Puerto Rican migration to the US, with some predictions suggesting upwards of 200,000 per year, some of which is doubtless the result of horrific hurricanes (Goldstein, 2018).

The Puerto Rican example points to a caveat. Old educational foundations and their rhetoric may overlap new ones in some locations, in this case a problematic mix. 


\section{Education as a Complement to Victory - Occupation Imperatives - 1945-1951}

As the foregoing suggests, colonial education was not something invented out of whole cloth. It was built, in both the Philippines and Caribbean, over and with systems in place before American colonialism there. As the $20^{\text {th }}$ century progressed the responsibilities of American educators expanded dramatically as US military and economic power expanded. Many patterns of practice and influence noted above remained in place, including the use of a high level commission, and military leadership and responsibility for managing strategy. Challenges included the wreckage of war, the unique character of systems in need of reform, and putting American ideals into practice. It is fair to observe that these ideas came to constitute a powerful form of ethanol-centrism which motivated Americans to support international education throughout the $2 \mathrm{O}^{\text {th }}$ century.

\subsection{Germany - a Struggle to Create Post-war Reform in a Tradition Bound Decentralized System}

Germany is now one of America's major global military allies and economic partners. It has undergone a major transition from occupied and divided nation to full fledged unified partner in shifting US imperial policies and practices increasingly global in character. A brief review of occupation era US educational initiatives shows a continuity of policy and programs developed in the Philippines and Puerto Rico. Programs and intergovernmental relations were doubtless aided by the fact that German - Americans are the largest immigrant group in America, approximately 58 million claiming German descent, with over 200,000 immigrants between 1960 and 1970. (Germans, 2018). During and after the First World war they faced ridicule and discrimination in the US, something they clearly strove to avoid again, in spite of the support and admiration many showed, often with the support of prominent US business and political leaders, to Hitler, who fed American anti-semitism, offered major new European markets and was seen as a bulwark against communism.

From 1945 until 1949 America and its allies Britain, France and the Soviet Union, participated in a major program of denazification in Germany, parts of which the US occupied. Its objective was to purge former Nazis from most important jobs and identify many for trial, and open the door to democracy, in part through reform of the German educational system. Given legitimacy by the Potsdam agreement and to be administered by the Allied Control Council (ACC), in the words of Taylor, "the United States military pursued denazification in a zealous, albeit bureaucratic, fashion, especially during the first months of the occupation." (Taylor, 2010, p.253).

Denazification began in January 1946. Unlike in the Philippines, where the military was given the initial responsibility for building schools and teaching American values, Angulo writes that organizational charts claiming military responsibility were one thing, but actual responsibilities another (Angulo, 2012). As in the case of the Philippines and Iraq (see below) the US simply did not have the resources to itself rebuild systems destroyed by the attacks of the US and allies. Wherever possible it had to rely on local support. In the words of Grimm, the occupiers "had noble ideas about democratizing and denazifying German schools, but the severe lack of resources and large amount of destruction seriously curtailed their efforts." (Grimm, 2010, p.1) This 
is a view supported by other scholars (Taylor, 2011). It is a good example of soft power rhetoric in service of rapidly changing geo-political requirements that could not be delivered upon.

There is good reason to believe that denazification's educational philosophy reflected sentiments which held that the democratization of German schools was a key to regional stability. It was in part a precursor to the Marshall Plan, and was an early reaction to plans by the American Hans Morganthau to radically divide a de-industrialized Germany into an agricultural economy. (Dorn, 2007, pp.163-166) (Blum, 1967).As Hirsch and Pine point out, denazification's primary education focus was to infuse a reformed German system with US ideas with the help of new teacher and administrator training, evaluation programs, and instructional materials. A challenge was to overcome the values and practices of Nazi youth programs as well as parents and teachers forced to support Nazi philosophy and practices during the Hitler years. (Hirsch, 1988)(Pine, 2010).The program took on added urgency with the beginning of the Cold War in 1947 and, as the Americans were to learn, they had to be careful to overly characterize an inherently conservative educational system as a Nazi one.

In light of the resource issue and to put some muscle into its efforts the US brought in a top level mission, not entirely unlike the Monroe Commission in the Philippines. Supported by the National Education Association and chaired by George Zook, president of the American Council on Education. It issued a report which was criticized by the Germans and many Americans because it called for a new national system which included comprehensive schools, replacing the character and power of the elite gymnasium system that was based and controlled in local districts (Mitchell, Crowson, \& Ships, 2011).

The numbers further show a significant challenge beyond structural change. Of the approximately 20 million German youth in the system, the majority of who were in lower grades, historically very few of them attended college. In the 1950 s for example, 80 percent had only Volksschule "primary school" education of 6 or 7 years. And many were highly demoralized due to ravages of war. As in much of Europe at this time only about 5 percent of youths entered college at this time and still fewer graduated. In the 1960s, 6 percent of youths entered college. As Beckert points out, some cities e.g. Hamburg had closed most of their schools long before wars end thanks to cataclysmic bombing. In 1961 there were still 8,000 cities in which no children received secondary education. In addition to the need to rebuild schools, all of Germany faced a huge refugee problem of 12 million people, with many refugee children to educate (Fuhr, 1997, p.4).

To make matters more complicated, Shibata writes that "compared with American egalitarian education, German education was framed by various social divisions in class, gender, region and religion. Specifically, the class-affected multi-track school system and the charging of tuition fees were in opposition to the American ideal of egalitarian education" (Shibata, p.124). It is no surprise that teachers, the Catholic Church and many others opposed American ideas for more universal and comprehensive education. There was not the reception Americans faced in the Philippines, Japan and other countries, where comprehensive education was looked upon by many in the educational establishment as a possible route to democratization and statehood.

According to Grimm, a mix of American organizations, public and private, 'soft' and 'hard' power in orientation, joined in reform efforts. 
"The most extensive re-education measures were implemented under the American occupation. The Office of Military Government for Germany US OMGUS, under the US zone's Military Governor General Lucius D. Clay, it allocated $\$ 1.03$ million to the education program in the period to 1948 , while the amount increased to \$48 million between 1949 and 1952 under the Office of the High Commissioner US, Germany HICOG. In addition, by 1949 rehabilitation programs were already being undertaken in West Germany by more than 50 private American organizations, including the American Council on Education, the labor unions AFL and CIO, the League of Women Voters, and the Rockefeller and Ford Foundations" (Grimm, 2010, p.1).

Despite the fact that some progress was made, German portrayal of American plans as "foreign" won the day and denazification was reemphasized as the German government pushed to free many prisoners, including those convicted of "low level" crimes, in part to foster internal healing and build a prosperous modern state to fight the influence of the Soviets (Williams, 2003).

In higher education circles there was tremendous respect for German universities, many of which had housed and trained Americans, including the first ambassador, William Dodd, a politically liberal University of Chicago professor, to Germany during the early years of the Hitler regime (Larson, 2011). This said, Germany's universities had harbored many Nazis and lent support to events like book burnings. In this climate Americans had their most success in the founding by U.S. occupation authorities in 1948 of the Free University of Berlin, which has developed close ties with many American and European universities. It included a significant relationship with the host city and a broad representation of faculty and students. More than meeting educational requirements, it came to be new weapon in East-West competition for influence in Germany, perhaps one of the most significant accomplishments of occupation strategy and an example of how education could serve larger political requirements. Regardless of outcomes, the politics and programs of occupation were soon to be overcome by Cold War ones which led to some practices the US used earlier in the century.

Another US tactic promoted a major set of exchanges, in which Germans initially studied what was called "the American Way of Life" in theory and practice. They were promoted by the military and a range of American institutions, foundations and agencies, in part to counter the Soviet practice of sending large numbers of German Democratic Republic students to Moscow, and in part to foster educational change and reform. As in the Philippines over fifty years earlier the foreign visitors were expected to return home and institute features of the US system in German schools, not so much as to support colonialism and area imperialism, but the building of West Germany as a powerful anticommunist Cold War ally. Accordingly, by the late 1960s and early 1970s, German education entered a period of reform in which approximately 12,000 Germans visited the US (Konzer, pp.148-9). Results included lessons learned and applied about civic education, team teaching, student participation in student councils and new German research on these and other topics (Kozner, pp. 160-161).

Taking the long view, it can be argued that American influence has been significant. One report suggests the German-American Fulbright Commission, for example, has sponsored over 300,000 scholarly exchanges since its creation in 1946. It was reported in 2011 that "the United States was the top-ranked destination for German high school 
students studying abroad and that Germany was the top-ranked destination for American high school students," many of German descent, studying abroad (Seavey, 2018, p.2).

The significance of US involvement in Germany after the war is best understood as the forces of occupation and immediate denazification gave way to the full emergence of the Cold War and an a growing international US imperialism which has included the support of the Federal Republic of Germany (West Germany). Significant populations in both countries express doubts and concerns about the relationship, partly in light of the extent and complexity of a US engagement which includes approximately 5,000 German troops in Afghanistan supporting the US led NATO coalition, and its defense ministry suggesting more will be sent (Pew, 2015)(Reuters, 2017).

\subsection{Reconstruction in Japan - Philosophical, Historical and System Coherence}

By the beginning of the $20^{\text {th }}$ century Japan embraced and implemented western technology and related ideas in support of nation building as an outcome of the Meiji Restoration which focused on industrialization. It borrowed ideas from schools abroad and hired foreign teachers at high salaries. It funded foreign study. There was a heavy focus on scientific and technical topics as well as German higher education. It looked to the US for industrial law, agriculture, cattle farming, mining, communications, commercial law (Nakayama, 1989, p.100). Japan had not been a Western colony subject to forced importation of curricula and structures (Zha, 2004).

According to Shibada, between 1868 and 1874, the government spent nearly one-sixth of the annual national education budget in dispatching over 500 students to Western countries: 209 students to the US, 168 to Britain, 82 to Germany and 60 to France in exchange programs similar to the practice of the Philippines. Meritocratic principles were applied to university appointments and professional standards for their faculties supported (Shibada, p.14).

There were deep splits between civil service and military elites, before the war, as economic, political and military strategies to build a powerful state took place (Passin, 1965). But the system worked well until the growth of militarism in the 1930 s and the catastrophic events of World War II. The Japanese educational system was modeled on Germany's, with "Gymnasien" selective grammar schools and universities to train students after primary school. Later, during the occupation Japan's secondary education system was changed to incorporate three-year junior high schools and senior high schools similar to those in the US: junior high school became compulsory but senior high school remained optional (Yamasaki, 2010).

Throughout the occupation, led by General Douglas MacArthur and ending in 1951, much of the Japanese government remained in place (Cohen \& Passin, 1987). What needs to be emphasized is that an important foundation for American interest in Japanese education must be seen, not only in terms of American ideals about the reform of Japan, but in light of US geo-political interests. These were heightened by the Communist take over of China and the Korean War. Unlike the case of Germany, the Japanese in America underwent forced removal to camps during WWII and their numbers remain relatively small, at 1.3 million (Japanese Census, 2018).

From a policy perspective the United States was in the position of an imperialistic power that to this day meant occupation of former Japanese territory (e.g. Okinawa) and considerable early, 1945-48, influence in Korean education exercised by the US. Army 
Military Government in Korea, which proposed a democratic system that came to be opposed by the authoritarian South Korean government after the Korean war (Millet, 2005). One important difference with the US occupation in Germany is American fascination and hope for a full economic and political recovery in a country for which it showed much admiration. Another is that Japan is utterly dependent on American military power in a part of the world where there continues to be considerable instability and nuclear threats.

Americans, under the energetic management of MacArthur, would be introduced to a Japanese education that was not the mixture of local state authority, philosophy and tradition that mired the many aspects of German education. In addition, Americans had a fascination for Japanese culture, influenced in part by the application of some anthropological precepts borrowed from Ruth Benedict's Chrysanthemum and the Sword. Written originally for US. Office of War Information in 1946, it explained Japanese tensions and contradictions in Japanese culture, and in particular its imperial system, in ways that persuaded many Americans, and some Japanese, that US policy makers understood the culture in which they were working (Benedict, 1946).

Japanese education was susceptible to America's ideas given its history of rejecting traditional Asian models in favor of its modernizing Western choices, including the purging of militaristic literature from the schools. The higher education sector modernization allowed a growth inducing restructuring. As a result, 201 universities and 149 junior colleges were created in place of the 45 universities and 177 colleges that existed before the War. Numbers of university admission increased to $17 \%$. Notwithstanding, much elitism remained in the system (Zha, 8).

In an effort to change Japanese postwar attitudes in favor of democratic ones, any nationalistic, militaristic, authoritarian, or anti-American content was removed from learning materials. This practice was known as suminuru, and was used as the primary method of educational reform until the newly fashioned, texts, Kuni no ayumi Footsteps of the Nation, Nihon rekishi Japanese History, and Minshushugi Democracy, which were written by what is now the Ministry of Education, Culture, Sports, Science and Technology (MEXT) and is responsible for educational administration (Buono, 2017).

The foundation provided by US occupation education set the stage for subsequent Japanese participation in the American empire in terms of complex military, economic and cultural relationships that have continued into the $21^{\text {st }}$ century. Successful Japanese manufacturing at home and in the US, particularly in the auto and electronic products industries, where Japanese products have replaced US ones (and are now under pressure from Chinese and Korean products), has raised concerns about the possible 'superiority' of Japanese culture, including education, if not Japanese genetic superiority itself (Itzkoff, 2005).

\section{Post-World War II Imperialistic Tools - A Complex Mix}

American status as a "super power" was built on the remnants of the Cold War and featured enmeshment in regional wars and economic competition with China, Japan and other nations. Vast international systems of commerce, energy, banking, and communications emerged, often to US advantage, and that of many politicians and private interests which promoted interventions. 
America's global power and influence was based therefore on far more than military power, significant as that was. Its foundation also included expressions of 'soft power' to complement (not replace) the 'hard power' of treaties, military relations and commercial involvement, such as the production of cheaply manufactured goods to be sold to American companies. The launching of the Peace Corps by President Kennedy in 1961, which assisted education in the nations where it was posted, is a very good example of government sponsored soft power that remains in existence.

\subsection{Examples from the Muslim World}

As in the once remote Philippines American educational influences followed the development of geo-political interests in much of the $20^{\text {th }}$ Century that, in the Muslim world, included direct US involvement, often with major military or CIA intervention, in Iran, Iraq, Libya, Syria, Afghanistan and other nations. Close educational ties in higher education preceded wars, particularly in such fields as engineering and anthropology in several countries. Most of that has faded in light of American interventions and the 'war on terrorism.' One measure of military involvement is cost, a Brown University study reporting the military and social costs to the US of them has been approximately $\$ 5$ trillion (Shane III, 2016).

US educational relations in far off and remote Afghanistan, where American remains in the longest war of its history, took place in the early years of the Cold War, and illustrate how a mix of institutional and government efforts collapsed. They included the active role played by Teachers College, Columbia University. From 1955 until 1975, Teachers College, arguably America's leading teacher training and educational research institution, managed a US Foreign Aid Program called the Afghan Project to work with local educators to create texts, and increase the number of schools and teachers in the country. Intended in part to counter growing Soviet influence in the region, it was directed by historian and civic education expert R. Freeman Butts of Teachers College, a prestigious member of the faculty.

Some project components were very large, containing as many as 35 Teachers College staff and 100 Afghans collaborating on various projects, which included one to develop a faculty of education for Kabul University (Teachers College, 2017). There were common explanations, heard by the author, Ronald Goodenow, who had appointments at Teachers College in the 1970 and 1980 s, that, ironically, this seemingly soft power program, and its democratic values, radicalized many students determined to overthrow Afghan royalty and created an unexpected hard political reality. Radicalized students were seen as a revolutionary vanguard by Soviet Union, leading to invasion and then defeat followed by US occupation (Barfield, 2012) and, unfortunately for historians, the destruction of records. That occupation grew significantly after the 9/11 terrorist attack in New York. As for a school of education, there was a renewed effort, with UN support, in 2003, to rebuild one (Goldman, 2003) and US support of colleges and schools continues to grow.

On its current web front page, the American University of Afghanistan claims that "Modeled on American Curriculum and standards, AUAF delivers 21st Century skills and competencies for overall student success and achievement." Founded as Afghanistan's only private university in 2006, it notes that its use of "American" in the title refers only to the use of the American credit system and English language (AUAF, 2017), a comment that presumably applies to the "American" universities to be found in other locations, including Muslim ones, including Nigeria, Dubai, Cairo, Beirutand 
other locations, many of which claim to focus on specific topics, including democratization, development, and healthcare. Some work closely with US universities, as in the case of Armenia the University of California at Berkeley (America Armenia, 2018), and Kyrgyztan's with Notre Dame (America Central Asia, 2018). All feature the US credit system and instruction in English.

Other efforts in Afghanistan have included efforts to educate girls, such as a school sponsored by Razia's Ray of Hope, in an area outside of the capital Kabul. Founded by a Massachusetts resident of Afghan descent, it is supported in large part by Rotary International and other contributions and volunteers. Its curriculum is organized to prepare female students for university acceptance and life in a country where such opportunity has been rare. It is sustained in country with the support of local tribal and other authorities who protect it. (Razia, 2018)

US. occupations did not lead, unlike in the Philippines, Puerto Rico, Germany and Japan, to new or reformed educational systems in the Muslim world.

In Iraq US interventions, which included significant American, British and other occupation forces, have had a devastating impact on education, and they have done relatively little to rebuild. A report by Sulfa Al-Shaikhly and Jean Cui documents the crippling of Iraq"s educational infrastructure by a succession of wars from the Iran-Iraq one, which the US supported, in the 1980 s through the current conflicts in the country, with the worst damage being done after the US led invasion in 2003.

They report estimates which suggest that 84 percent of the country's institutions of higher education had been "burnt, looted, or destroyed by 2005. Public school damage has resulted in half the central Iraq schools fail national construction standards and over a million children could not be accommodated, not including the large number of dislocated and refugee children (Al-Shaikhly and Cui, 2015). Matters are made worse by the large number of Iraqis who have emigrated elsewhere, generally in Mesopotamia, and very difficult visa processes which have hindered exchange programs and made it extremely difficult for Iraqi academics and administrations to visit the US (Bull, 2008).

US help has been scarce. State Department and UN/World Bank sources have requested $\$ 3.2$ billion for assistance. Approximately $\$ 8$ million has been approved by Congress (Watson, 2015). The US's Iraq embassy website promotes exchanges and the use of reference services on higher education. When consulted for this publication it warned that the site had been hacked and should only be used with caution (Education USA, 2017, pp. 1).

\subsection{Country Specific Programs and Exchanges - A Mix of Philanthropy, Universities, Business Schools, and the US Government}

The shape of American educational imperialism is currently a complex mix of institutions, organizations and prominent individuals which promote the uses of higher education and schooling to build a more democratic and prosperous world. By all accounts there has been a growing set of international educational relations between nations and educational transfer in response to an important question by Eisemon about the nature and status of their existence (Eisemon, 1977).

Philanthropic foundations are a highly visible component of this mix. They now play a major role in facilitating international conferences, exchanges and research as well as direct support for schooling and higher education. They represent examples of 'soft power' components of imperialism which radiate internationally from the US. This said, 
historically, as in the case of the Ford Foundation working closely with the CIA to support anti-Allende policies which led to death and destruction in Chile (Saunders, 2000), some have doubtless participated in undemocratic efforts to support Cold War and other political objectives.

Looking at the big picture, Stephen Heyneman and Bommi Lee write of foundations that:
"Though basic education continues to dominate education aid, funding is also directed towards a wide variety of other priorities. These include secondary education, teacher training, adult education and literacy, science education, vocational skills and higher education. In many cases, private foundations and nongovernmental organizations focus on particular areas. For instance, the Ford and Carnegie Foundations have concentrated on higher education, while the Open Society Institute sometime called the Soros Foundation has focused on primary and secondary education, and on civics education in particular." (Heyneman, Lee, 2013, p.1)

The Carnegie Corporation is a good example of US philanthropic efforts abroad, a key component of imperial education which engaged often with local in-nation interests as often stimulating mulch-national efforts.

Carnegie aided library building activities in Africa, funded the Ashby Commission to study African universities in 1959 and underwrote conferences, perhaps the most important ones being a meeting on African education at Princeton in 1960 and another on the role of universities in teacher education at Lake Mohonk, New York, in 1964. Carnegie was especially interested in supporting the development of institutes of education in the Third World and was to underwrite the East African teacher training programs which led in part to the founding of the Peace Corps in 1961.

The Carnegie Corporation has tended to offer direct grants (Goodenow, Issues), while Ford, Rockefeller other foundations have developed their own assistance modes. The Ford Foundation spent $\$ 38,000,000$ on "university development" alone between 1955 and 1977. With the coming of independence in several countries, that number would decrease (Goodenow, 1984). In 2016 Ford spent $\$ 144,373,729$ outside the US. Topics at conferences and other activities included climate change, civic education and responsibility, and internet freedom (Ford, 2018). In the 1960s, at the height of foundation interest in international education one hundred fifty-two foundations spent approximately $\$ 141,000,000$ in international activities, much of which went to support international studies in the United States, primarily in cooperation with universities and research institutes.

The United States Congress created the Fulbright Program in 1946, in the aftermath of World War II, to promote what it called 'mutual understanding' between the United States and the rest of the world, an objective that while laudable doubtless serves the interests of imperialism. This program's foremost advocate, the late Senator J.W. Fulbright (Powell, 1996), a multilateralist who supported the United Nations and opposed the Vietnam war, presented the bill to establish an educational exchange program only weeks after the dropping of the atomic bomb in Hiroshima and Nagasaki. Over the years, the Fulbright Program has developed into the world"s largest, best-known and most prestigious educational exchange program and has provided over 370,000 scholars and students with the opportunity to lecture and study abroad. It is at the top of the list of US government based educational and cultural imperialism, an illustration that 'imperialism' contains components which enable many worthy causes. 
Today, there are over 160 countries, including Japan, which have participated in the Fulbright Program, playing an important role in fostering the development of leaders in various fields (https://eca.state.gov/fulbright). It is a powerful educational tool of American Imperialism, a useful example of government sponsored soft power.

The US-Japan Foundation, founded in 1981, and located in New York, priority support for students at elementary and secondary levels in the US to receive grants, as did primary and secondary schools and teachers, to learn about Japanese culture. Universities obtained support for training precollege teachers. "Core Groups" brought talent together to address issues related to the environment, security and other important issues. This was supplemented by exchanges (US Japan, 1981).

There are many examples of high level collaboration between philanthropic, NGO, inter-governmental and government agencies and widespread uses of information technology to provide international assistance and collaboration (Goodenow, 2015) which defy simple soft power classification.

In Asia, Africa and other parts of the world the US State Department primarily, in collaboration with the United Nations, World Health Organization, national governments (e.g. Pakistan, Nigeria), the Gates Foundation and other NGO's have engaged in major, \$7billion medical and educational efforts to eradicate polio, a largely successful effort led in large part by Rotary International (Endpolio, 2018). In Afghanistan, Pakistan and Nigeria, where militant Islamists have opposed the effort violently, governmental and tribal support has been significant and polio is now within a dozen cases a year away from eradication. It is to be noted that much of the opposition to this program is based on fears that it is a ploy of American imperialism to kill Muslims with the help of governments, such as Nigeria and Pakistan, seen as compliant in American imperialism.

As for the US government itself, The United States Agency for International Development in the years 2011-2015 supported 151 basic education programs in 45 countries, benefiting approximately 42 million children and youth. Focus areas include the education of girls; USAID collaborates with other agencies, donors, country governments and civil society. Its website includes many program reports (USAID, 2017)

\subsection{The Transfer of Educational Progressivism}

As far back as the 1920s prominent educators strove internationally to, as Bello suggests, promote increasingly an ideology of democracy. Many were in the camp of what was coming to be known in the US as 'progressive education.' (Cremin, 1964) It was complemented by the emerging 'new education' which arose in the UK and its empire and whose New Education Fellowship, founded in 1921 came to resemble and occasionally partner with America's Progressive Education Association (Jenkins, 2010) They had in common a promotion of 'child centered' education based in part on a critique extremely critical of traditional schooling which was more aligned with European colonialism and helped make American imperial education more palatable domestically (Bello, 1998, p 367)

Individuals, such as George Counts, George Zook and R. Freeman Butts, cited above, played important and highly visible roles abroad. A good example is John Dewey, the prominent Columbia University philosopher of education who promoted 'learning by doing' based on observation and trial and error (Dewey, 1938) as part of a larger battle to use education to foster democracy (Dewey, 1916).

Accordingly Dewey, in a widely distributed article for a Chinese publication in 1922, after two years in China (Wang, 2007), aligned himself with the proponents of a 
"scientific" approach, writing that the best way to change minds is "to change the conditions with shape them rather than go at it by direct appeal and exhortation" (Dewey, 1922, pp.1-2). His main worry was that the world was not civilized enough to permit close cultural contact without ill effect.

This all, he argued, led to a need for scientifically based cures which included education and what he called political and industrial organization (Dewey, 1922, pp.14-15). In 1925, he worried about a war between Europe and Asia, citing exaggerations by Christians that Muslims want to exterminate them. His solution was the use of US financial power, certainly an imperialistic ploy, to oppose the international use of force to undercut antidemocratic European rivalries in Asia (Dewey, 1925, pp.229-30). This all notwithstanding, There is no doubt that Dewey and his followers represented a highly optimistic and if not "cheery, as put by Sobe, side of American influence (Sobe, p.9).

There is evidence that Dewey and others who shared his views influenced education on American Native American reservations which in turn influenced programs on community education produced by the Mexican revolution. (Goodenow, 1980) Others of particular influence included William James, G. Stanley Hall and William Heard Kilpatrick. Mexico, Chile and other Latin American nations sent large numbers of educators to the US to study with them, often supported and hosted by the international New Education Fellowship and the US Progressive Education Association (Brainerd, 1928, p.467).

Though it may be argued that "ideas" were important in American colonial education, and Dewey, as an example, had influence abroad, the breadth and overall scope of American education does not feature philosophy. It tries to emphasize American conceptions of democracy and international relations, often in the guise of nation building.

Literature from the 1930 s and 1940 s reveals extensive efforts to reform Latin American education, often through conferences and collaborative work on publications with agencies and organizations of other countries, a growing form of international educational relations. Chile was a particularly tragic case because after World War II it was rapidly becoming a powerful force and showcase in education, forming professional organizations, striving for gender equality, and introducing child-centered practices, a trend undone by the coup against its leftist government in 1973, ushering in the prosecution teachers and administrators, and raising serious questions about CIA and US foundation involvement in what was clearly Cold War policies as applied to Latin America (Dinges, 2005).

At best, in the face of depression and widespread traditionalism, results were limited in Latin America, and in the case of Chile later eventually catastrophic. As time went on institutions such as Teachers College showed interest in Africa and developed collaborative relationships with other schools of education, Teachers College teaming up with the University of London Institute of Education in African reform efforts (Goodenow \& Cowen, 1986, pp. 271-289). Given the many changes taking place in American education in the 1970 s and 1980s, particularly in urban education, as this author argues, there is much to study in terms of international collaboration and communication and how American ideas on reform were disseminated globally (Goodenow, R. \& Marsden. W., 1992, Goodenow introduction).

\subsection{Business Education}

The mix of US influence includes organizations which go to the heart of economic expansion and influence. American business schools have collaborated extensively with foreign 
universities to set up joint research, exchange, leadership training and other programs, often with the assistance of alumni living abroad. Prominent among them are the Harvard Business School, the Tuck School of Business and the Sloan School and MIT. They have played an important role in the rapidly growing development of MBA programs, which are proliferating, particularly in Pakistan, Indonesia, India and China. Regional cooperation and business expansion, organizational development and leadership, new consumer markets, climate change and other environmental issues are on the curricular agenda. In recent years business ethics has become more prominent. Many business schools work closely with the World Bank and other international agencies (Goodenow, 2018). They and schools of education seldom offer critiques of capitalism or American imperialism, but they are in the mix of soft power influences.

An example of on-going relations with an American business school, the Harvard Business School Club of the Philippines is available to graduates of the Harvard Business School or who had spent a year in a Harvard program leading to a degree, as well as Harvard Business School faculty and staff. Its goals include describing case studies, showing its own capabilities, leadership development and fostering nation building and regional relationships. It is currently rebuilding an elementary school destroyed in a hurricane. The club's web site presents case studies of successful Philippine companies, and the commentary and research of Harvard faculty on the Philippines. It is a good example of the growing trend in business schools to promote "social responsibility" in the MBA curriculum and in corporations (Harvard, 2018)(Goodenow, 2018). Much of modern American imperialism includes its adherence to a capitalism which thrives on business education, and enhances the power of business schools at home and abroad.

\subsection{A University Enabled Wartime Program}

From 1955 until 1962 the Michigan State University Vietnam Advisory Group (MSUG) was a US State Department program which intended to offer technical assistance for the purpose of nation building. Areas of focus included police and public administration, and economics. The program, which operated separately from most US agencies, had doubtful impact on the South Vietnamese government, though it helped write a national constitution, but was ended when American educators in the program began to express criticism of the South Vietnamese regime in US publications and faced demands for the termination by President Diem. Despite MSUG efforts to put a more accommodating faculty in place in order to save a lucrative contract, Diem persisted and the program was ended in 1962. Subsequent investigation showed the importance of CIA influence, which made the program subject to considerable anti-war protest in the US.(Ernst, 1998).

Michigan State has provided access to its extensive program archive on line (Michigan State, 2018). As with many US programs, this one featured faculty exchanges, the granting of advanced degrees to South Vietnamese participants and the use by Michigan State of faculty from other universities. Its end results, according to Ernst (1998), were very meager, consisting mainly of such things as small arms training, getting handcuffs for policy, advice on decentralized bureaucracy, and a national identity card (used by the government to track down dissenters). The program's significance for this article is that it included both a mix of participants and sponsors that did not have, as the case of many programs noted above, the political support or resources to carry out its mission, and that it was closely allied with American efforts, some of which were clandestine, to both support an existing regime known to be unpopular and the general objectives of winning a Cold War battle and extending US imperial interests in Southeast Asia, an effort that failed catastrophically for the United States. It was also a mix of hard and soft power. 


\section{Concluding Perspective: Shape, Shifts and Mix}

If there is a 'shape' to American educational imperialism it is a mufti-dimensional and multi-layered one, a history of well over 100 years complemented by a growing and complicated mix of alliances, NGOs, universities, influential individuals and intergovernmental support of 'soft power' applications. Less visible in this collection is the military, which has had diminished educational involvement following its long history in the Philippines and more recently in the post-war occupation period in Europe, a significant shift. In some cases, as in Vietnam, clandestine services such as the CIA are involved.

Educational imperialism also includes what would seem to be anomalies, as in the case of Puerto Rico, which remains a colony. Disasters, such in Afghanistan's Teachers College involvement, or the Ford Foundation in Chile, and program failures, as with the Michigan State one in Vietnam, may follow these alliances no less than educational catastrophe in Iraq which was severely damaged without US reconstruction. In total, the word 'mix' is an important one. Mix of modalities, motives and outcomes.

The same may be said of education, where a mix of policies and practices reflected assertions of democratic intent, playing an important role in claiming to prepare territories for possible independence and close relations with the US. Education as an important component of diplomacy was in part the application of national interest and knowledge to reform, build or support systems was a narrative with a belief system reflective of America's long-standing claims to being a champion of 'democracy.'

Shifts in educational imperialism are impacted by changing political ideas and forces in the United States, as it went through the main phases noted above. In the case of the Philippines and Puerto Rico prevailing political views focused on consolidation, with background debates on these engagements common in political and press circles. After a period of isolationism supported by the major political parties the Second World War and occupations Germany and Japan featured early political support for reform, with the Cold War bringing in a consensus for fighting communism on cultural, economic, and, as in Korea and later Vietnam, using military and clandestine means. After 9/11 the 'war on terror' led to politically supported interventions. Given changes in the domestic US economy business education became increasingly popular and must now be seen as a part of US influence abroad which corresponds directly to multi-national corporate support.

Increasingly a major growth in America's place in the world has led to shifts in educational programs which, while building on a history of exchanges, featured powerful institutional and individual influences which doubtless benefited both a broader imperialism and institutional interests, some of which were presented, as in the case of Dewey, child centered education, and the uses of "scientific" studies to justify "expert driven" policies."Democracy" and "the American way" were so embedded in programs they could be attractive at home and abroad, regardless of actual nature of far off engagements and whether democracy itself was a factor, which it often was not. What remains to be understood is the extent to which conventional public support for 'the American Dream' understood that foreign military, trade, and related strategies, despite corresponding soft power efforts, have undermined it at home and abroad. (Prestowitz, 2012)

One can argue that these changes took place, in programs such as the anti polio one, thanks to new medical and communications technologies which enhanced communication, educational relations, collaboration and research, much of which was centered in the United States. Looking forward, the impact of new information technologies on 
relationships and transfer will doubtless be another chapter in nature of American imperialism, and whether it grows or is reduced by forces of what is now known as the global economy or the more commonly used (and abused) term 'globalism'. The coming to power in the US in 2017 of a government which, in rhetoric at least, offers a full throated condemnation of them will pose additional challenges and opportunities for research and interpretation.

\section{References}

Al-Shaikhly, S. \& Cui, J. (2017, October 1). Education in Iraq. WENR. Retrieved from https://wenr.wes.org/2017/10/education-in-iraq

American Council on Education (May 2009). International Partnerships: Guidelines for Colleges and Universities, Appendix C: Funding Sources. Retrieved from http://www.acenet.edu/news-room/Documents/AppendixC-editKK-FinalUpdatedMayo9.pdf

American University of Afghanistan (2018). https://www.auaf.edu.af/

Angulo, A. J. (2012) Empire and Educaton: A history of greed and goodwill from the War of 1898 to the War on Terror (Kindle edition). Basingstoke; Palgrave Macmillan

Alumni Association American University of Afghanistan (2018). https://www.facebook. com/AUAF-Alumni-Association-218154425049283/

American University of Antigua (2018). https://www.auamed.org/

American University of Armenia (2018). https://aua.am/

American University of Central Asia (2018). https://www.auca.kg/

Barfield, T. (2016). Afghanistan: A Cultural and Political History. Princeton: Princeton University Press.

Beckert, H. (2016). The Effects of Denazification on Education in West Germany", (Honors Thesis, Murray State University), Retrieved from http://digitalcommons. murraystate.edu/cgi/viewcontent.cgi? article $=1015 \&$ context $=$ scholarsweek PDF 19

Bello. W, (1998). American Imperialism in the Asia-Pacific. Peace Review, 1O(3) https:// focusweb.org/node/342

Benedict, R. (1946). The Chrysanthemum and the Sword: patterns of Japanese culture. New York: Houghton Mifflin.

Blum, J. (1967). From the Morgenthau Diaries: Years of War, 1941-1945. Boston: Houghton Mifflin.

Brainerd, H. (1928, May), Progressive Schools in Latin America, Bulletin of the Pan American Union, 62, 453-467.

Bull, B, (2008). Project Aims to Bring Iraqi Students to U.S. Colleges, National Public Radio Retrieved from https://www.npr.org/templates/story/story. php?storyId $=90768387$. 
Buono, S. (2016, August 12,). Commission and Omission of History in Occupied Japan 1945-1949. Binghamton: Journal of History. Retrieved from https://www. binghamton.edu/history/resources/journal-of-history/stephen-buono.html

Cohen, T. \& Passin, H. (1987). Remaking Japan: The American Occupation as New Deal. New York: Free Press.

Cogan, J. (1984, March). Should the U.S. Mimic Japanese Education? Lets Look Before We Leap. Phi DeltaKappan, 65, 463-68.

Counts, G.S. (1925, October). Education in the Philippines. The Elementary School Journal, 26, 94-106. Retrieved from https://doi.org/10.1086/455838

Cremin, L. (1964). The Transformation of the School: progressivism in American education, 1876-1957. New York: Vintage.

Dewey, J. (1916). Democracy and Education. New York: Macmillan

Dewey, J. (1922). Racial Prejudice and Friction. The Chinese Social and Political Science Review, 6. pp. 1-2, 14-15

Dewey, J. (1925, April 22). Highly Colored White Lies. The New Republic, 229-30.

Dewey, J. (1938). Experience and Education. New York: Barnes and Noble.

Dinges, J. (2005). The Condor Years: How Pinochet and his allies brought terrorism to three continents. New York: The New Press.

Dorn, C. (2007), American Education, Democracy and the Second World War. New York: Palgrave Macmillan.

Education USA (2018). US Embassy Iraq. Retrieved from https://educationusa.state.gov/

Eisemon, T. (1977). Educational Transfer: The Social "Ecology" of Educational Change. Teachers College Record, 78, 359-369.

Endpolio (2018). Retrieved from http://polioeradication.org/

Ernst, J. (1998). Forging a Fateful Alliance: Michigan State University and the Vietnam War. East Lansing: Michigan State University Press

Fain, P. (2012). Hour By Hour. Inside Higher Ed. Retrieved from https://www. insidehighered.com/news/2012/09/05/credit-hour-causes-many-highereducations-problems-report-finds

Ford Foundation (2018). Civic Engagement and Government. http://www. fordfoundation.org/work/challenging-inequality/civic-engagement-andgovernment/

Fuhr, C. (1997). The German Educational System Since 1945. Bonn: Inter Nationes. European Reading Room, The Germans in America, Library of Congress. Retrieved 2018 from https://www.loc.gov/rr/european/imde/germchro.html 
Goldman, J. (2003, March 16). Afghan Schools to Get an Education, Los Angeles Times, p. 16 , http://articles.latimes.com/2003/mar/16/nation/na-schools

Goldstein, M. (2018, March 5). Puerto Rico's Positive Business Slogans Can't Keep the Lights On.New YorkTimes. Retrievefrom https://www.nytimes.com/2018/03/o5/ business/puerto-rico-business-maria.html

Goodenow, R. (1977). The Progressive Educator as Radical or Conservative: George S. Counts and Race, History of Education, 25, 5

Goodenow, R. (1980, summer). Progressive Educators and the Native American. History of Education Quarterly, 207, 16.

Goodenow, R. (1984, summer) Transcending the Legacy of $20^{\text {th }}$ Century American Schooling: In Search of a Global Perspective. Issues in Education, 44-55.

Goodenow, R. (1986). "The International Educational Relations of the United States". Lecture, University of London Institute of Education

Goodenow, R, \& Marsden, W. (1992) The City and Education in Four Nations. Cambridge: The Cambridge University Press

Goodenow, R. (2012). Paradigms and Practice: Perspectives on Ever Shifting Telework Sands. In E. Christopher (Ed), Managing Communication Across Cultures: Different Voices. London: Palgrave MacMillan

Goodenow, R. (2015). Service Across Cultures: A Case Study of the Emerging Role of Communication Technology in Rotary International. In Elizabeth Christopher, International Management and Intercultural Communication; a Collection of Case Studies, London: Palgrave MacMillan.

Goodenow, R (2018). From occupation to cultural and social responsibility in Philippine and PuertoRican business education: A first stage historical research perspective. Forthcoming as Chapter 3 in Elizabeth Christoper (Ed), Meeting Expectations in Management Education: Social and Environmental Pressures on Managerial Behavior. London: Palgrave MacMillan.

Goodenow, R. \& Cowen R. (1986). The American School of Education and the Third World in the Twentieth Century: Teachers College and Africa, 1920-1950, History of Education 15, 271-289.

Grimm, S. (2010). Germany's Post-1945 and Post-1989 Education Systems. World Bank, World Development Report, March 2010, 1.

Harvard Business School of the Philippines http://www.hbsph.com/s/1738/cc/index. aspx?gid=38\&pgid $=61$

Heyneman, S, \& Lee, B. (2013). International Organizations and the Future of Educational Assistance. ReCom, United Nations University, WIDER Working Paper No. 2013/018, 9-22

Hirsch, H. (1988, Fall). Nazi Education: A Case of Political Socialization. Educational Forum, 53(1), pp 63-76 
Institute of International Education (2017). http://www.iie.org

Itzkoff, S. (2005). Rebuilding Western Civilization. Ashfield: Paideia

Japanese Census Data (2018). United States Census Bureau. Retrieved from https://factfinder.census.gov/faces/tableservices/jsf/pages/productview. xhtml?pid=ACS_15_1YR_Bo2018\&prodType=table

Jenkins, C. (2010, November 10). New Education and its emancipatory interests (19201950). History of Education, 29(2).

Justice, B. (2009). Education and the End of a Gun: The Origins of American Imperial Education in the Philippines. In N. Sobe (Ed), American Post-Conflict Educational Reform: From the Spanish American War to Iraq. New York: Palgrave Macmillan

Koinzer, T. (2009). German Postwar Educational Reform and the "American Way of Life". In N. Sobe (Ed), American Post-Conflict Educational Reform: From the Spanish-American War to Iraq (p. 148). New York: Palgrave Macmillan.

Larson, E. (2011). In the Garden of the Beasts - Love, Terror, and an American Family in Hitler's Berlin. New York: Broadway Books.

Michigan State University (2018). Vietnam Group Archive. http://vietnamproject. archives.msu.edu/

Millet, A.R. (2005). The War for Korea: 1945-1950. Lawrence: University Press of Kansas

Mitchell, D., Crowson, R. \& Ships, D. (2011). Shaping Education Policy: Power and Process. New York: Routledge

Nakayama, S. (1989). Independence and Choice: Western Impacts on Japanese higher Education. In P. Altbach \& V. Selvaratnam (Eds), From Dependence to Autonomy: The Development of Asian Universities. Dordrecht: Kluwer Academic Publishers.

Navarro, J.M. (2016). Creating Tropical Yankees: Social Science Textbooks and U.S. Ideological Control. New York: Routledge

Nye, J.S. (2004). Soft Power: The Means to Success in World Politics. New York: Public Affairs

Sobritchea, C. (1996). American Colonial Education and Its Impact on the Status of Filipino Women. Quezon City: University Center for Women's Studies and the University of the Philippines. Retrieved as http://asj.upd.edu.ph/mediabox/ archive/ASJ-28-1990/sobritchea.pdf.

Passin, H. (1965). Society and Education in Japan. New York: Teachers College and East Asian Institute.

Pew Research Center (2015, May 7). Germany and the United States: Reliable Allies, But Disagreement on Russia, Global Leadership and Trade. Retrieved from http:// www.pewglobal.org/2015/05/07/germany-and-the-united-states-reliable-allies/

Pine, L. (2010). Education in Nazi Germany.London: Bloomsbury Press

Powell. L.R. (1996). William Fulbright and His Time: A Political Biography. Memphis: Guild Bindery Press. 
Prestowitz, C. (2012). Pivoting Away from the American Dream. FP, Retrieved from http://foreignpolicy.com/2012/01/o9/pivoting-away-from-the-american-dream/

Quintero, A.H. (2017). History of Education in Puerto Rico. Enciclopedia de Puerto Rico. Retrieved from https://enciclopediapr.org/en/encyclopedia/history-ofeducation-in-puerto-rico/\#1463492689874-dd12c211-136e

Razia's Ray of Hope (2018). https://raziasrayofhope.org/

Shane III, L, (2016, September 12), Report: Wars in Iraq, Afghanistan cost almost \$5trillion so far. Military Times. Retrieved from https://www.militarytimes.com/ news/your-military/2016/o9/12/report-wars-in-iraq-afghanistan-cost-almost-5trillion-so-far/

Siebold, S. (2017, December 20). Germany could send more soldiers to Afghanistan. Reuters. Retrieved from https://www.reuters.com/article/us-germanydefence/germany-could-send-more-soldiers-to-afghanistan-defense-ministeridUSKBN1ED24V

Seavey, R. (2018) .The Impact of Educational and Exchange Programs on GermanU.S. Relations. Johns Hopkins University, American Institute for Contemporary American Studies. Retrieved from http://www.aicgs.org/2018/o1/the-impact-ofeducational-and-exchange-programs-on-german-u-s-relations/

Shibata, M. (2005). Japan and Germany under the US Occupation: A Comparative Analysis of the Post-War Education Reform. Lanham: Lexington Books

Sobe, N.W. (2009). American Post-Conflict Educational Reform-From the SpanishAmerican War to Iraq. New York: Palgrave MacMillan.

Solomon, B. (2013). Ancestors and Immigrants: A Changing New England Tradition. Cambridge: Harvard University Press.

Stoner, F.S. (2000). The Cultural Cold War: The CIA and the World of Arts and Letters. New York: Free Press.

Silver, H. (1984, November 9). Educational Transfer or Educational Relations, The Times Higher Education Supplement, 14.

Stratton, C. (2016). Education for Empire: American Schools, Race, and the Paths of Good Citizenship. Oakland: University of California Press.

Tarnoff, C. (2016, Summary). Foreign Aid and the Education Sector: Programs and Priorities. Washington: Congressional Research Service,

Taylor, F. (2011). Exorcising Hitler: The Occupation and Denazification of Germany. London: Bloomsbury Press.

Teachers College (2002). The Afghan Project: TC Working with Afghans on Education. Retrieved from http://www.tc.columbia.edu/articles/2002/june/the-afghanproject-tc-working-with-afghans-on-education/

Teacherph (2016, May 16). US Basic Education Statistics in the Philippines. Retrieved from https://www.teacherph.com/basic-education-statistics-philippines/ 
USAID (2018). Retrieved from https://www.usaid.gov/education

US Department of State (2018). The Fulbright Program. Retrieved from https://eca. state.gov/fulbright

US-Japan Foundation (1981) http://us-jf.org

Wang, J. (2007). John Dewey in China. Albany: State University of New York Press.

Watson Institute, Brown University (2015, April). University Reconstruction in Iraq. Retrieved from http://watson.brown.edu/costsofwar/costs/social/education

Williams, C. (2003). Adenauer: The Father of the New Germany. London: Time Warner Books.

Yamasaki, Y. (2010, September 2010). The impact of Western progressive educational ideas in Japan: 1868-1940. History of Education, 39(5). 575-588

Zha, Q (2004). Foreign influences on Japanese and Chinese higher education: a comparative analysis. PDF Download retrieved from https://www.researchgate. net/publication/26409023 Foreign influences on Japanese and Chinese higher education a comparative_analysis 